$p$-ISSN 1693-9484, $e$-ISSN : 2621-8313

Majalah Ilmiah Bahari Jogja (MIBJ)

Vol. 18 No. 1, Februari 2020 (71-80)

DOI : $10.33489 /$ mibj.v18i1.229

(C) 2020 Sekolah Tinggi Maritim Yogyakarta

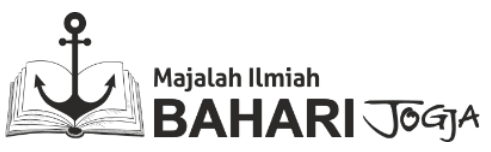

\title{
Transformasi SDM Dalam Menghadapi Tantangan Revolusi 4.0 di Sektor Kepelabuhan
}

\author{
Himawan Aditya Pratama ${ }^{1 *}$, Heni Dwi Iryanti ${ }^{1}$ \\ ${ }^{1}$ Prodi Transportasi, Sekolah Tinggi Maritim Yogyakarta, Jl. Magelang KM 4.4, \\ Yogyakarta 55284, Indonesia \\ *Corresponding Author. Email:himawan.aditya.pratama@gmail.com.Telp:081227522776
}

\begin{abstract}
Abstrak
Saat ini Indonesia sedang menghadapi era Revolusi Industri ke-4 atau Revolusi Industri 4.0. Maka dari itu revolusi industri 4.0 di sektor pelabuhan merupakan hal baik untuk menuju smart port dan smart supply chain. Seiring dengan revolusi industri 4.0 dan teknologi digital, persaingan bisnis dan pembangunan yang semula bertumpu pada pemanfaatan sumber daya alam akan bergeser pada penguasaan teknologi informasi dan kompetensi angkatan kerja. Di sinilah pentingnya investasi SDM. Era revolusi industri 4.0 membuka kesempatan bagi sumber daya manusia (SDM) di sektor manufaktur untuk memiliki keahlian yang sesuai dengan perkembangan teknologi terkini. Untuk itu, diperlukan pelaksanaan program peningkatan keterampilan (up-skilling) atau pembaruan keterampilan (reskilling) para tenaga kerja berdasarkan kebutuhan dunia industri saat ini.
\end{abstract}

Kata Kunci : Pelabuhan, Revolusi Industri 4.0, SDM

\begin{abstract}
At present Indonesia is facing the era of the 4th Industrial Revolution or the Industrial Revolution 4.0. Therefore the 4.0 industrial revolution in the port sector is a good thing to go to smart ports and smart supply chains. Along with the 4.0 industrial revolution and digital technology, business competition and development that originally relied on the use of natural resources will shift to the mastery of information technology and workforce competencies. This is where the importance of HR investment. The era of the industrial revolution 4.0 opened the opportunity for human resources (HR) in the manufacturing sector to have expertise in accordance with the latest technological developments. For this reason, an up-skilling or reskilling workforce program is needed based on the current needs of the industrial world.
\end{abstract}

Keywords: Port,Industrial Revolution 4.0, HR

\section{PENDAHULUAN}

Persaingan global yang makin intensif, teknologi yang berkembang pesat, pergeseran demografi, keadaan perekonomian yang fluktuatif, dan perubahanperubahan dinamis lainnya telah memicu perubahan kondisi lingkungan di sekitar bisnis industri. 
Saat ini Indonesia sedang menghadapi era Revolusi Industri ke-4 atau Revolusi Industri 4.0 yang bertujuan meningkatkan daya saing dan produktivitas industri nasional. Kehadiran revolusi industri 4.0 ditandai dengan otomatisasi dan digitalisasi. Hal ini akan membuat dampak yang berarti bagi masa depan industri di Indonesia. (http://hubla.dephub.go.id, 2019)

Hampir semua industri mengharapkan adanya otomatisasi guna mendorong bisnisnya, termasuk industri di pelabuhan. Maka dari itu revolusi industri 4.0 di sektor pelabuhan merupakan hal baik untuk menuju smart port dan smart supply chain.(krjogja.com, 2019)

Sektor kepelabuhan mencakup berbagai layanan, dimana layanan transportasi barang dan penumpang merupakan layanan yang utama. Layanan terkait lainnya yang termasuk dalam sektor ini adalah berbagai layanan pelabuhan (seperti bantuan pilotage, towing and tug, perbaikan darurat, tempat berlabuh berlabuh dan layanan berlabuh, dll.) Dan layanan pelengkap atau pendukung (seperti penyimpanan dan pergudangan, layanan penanganan kargo maritim, layanan bea cukai, dll.). (Nurqamar dan Asty. 2018)

Pelabuhan telah berubah menjadi simpul yang sangat penting bagi rantai logistik yang kompleks dengan tujuan utama peningkatan daya saing produk. Pelayanan pelabuhan menjadi penting, karena pelayanan yang diberikan oleh bisnis kepelabuhan tersebut berdampak signifikan pada penetapan harga akhir produk (OECD, 2011)

Kepelabuhanan Indonesia memiliki modal yang cukup baik untuk menerapkan industri 4.0. Ada dua hal yang mendukung pengembangan industri di era digital, yaitu pasar yang besar dan jumlah SDM yang produktif seiring dengan bonus demografi. (kompasiana.com, 2019).

Namun ketersediaan tenaga kerja juga harus selaras dengan kebutuhan pasar kerja itu sendiri, demikian diungkapkan oleh Bapak Khairul Anwar, Sekretaris Jenderal Kementerian Tenaga Kerja, pada acara Jumpa Pers kompasiana Akhir Tahun yang dilaksanakan pada tanggal 28 Desember 2018 lalu.

Seiring dengan revolusi industri 4.0 dan teknologi digital, persaingan bisnis dan pembangunan yang semula bertumpu pada pemanfaatan sumber daya alam akan bergeser pada penguasaan teknologi informasi dan kompetensi angkatan kerja. Di sinilah pentingnya investasi SDM. Sumber daya alam akan habis dieksploitasi dan melahirkan problem lingkungan. Tidak demikian dengan investasi SDM yang tak terbatas dan terus dinamis. (kompasiana.com, 2019).

Era revolusi industri 4.0 membuka kesempatan bagi sumber daya manusia (SDM) di sektor manufaktur untuk memiliki keahlian yang sesuai dengan perkembangan teknologi terkini. "Di dalam roadmap Making Indonesia 4.0, salah satu program prioritasnya adalah peningkatan kualitas SDM. Sebab, talent menjadikunci atau faktor penting untuk kesuksesan implementasi industri 4.0," menurut Menteri Perindustrian Airlangga Hartarto didalam kompasiana.com. 2019. 


\section{TINJAUAN TEORITIS \\ Revolusi industri 1.0}

Menurut Inovasi.com (2018) Revolusi industri merupakan suatu perubahan besar yang cepat dan radikal yang mempengaruhi corak kehidupan manusia. Sejarah mencatat sekitar tahun 1800-1900 merupakan periode Revolusi Industri 1.0. Inggris merupakan negara yang mempelopori terjadinya Revolusi Industri. Saat itu secara politik Inggris memiliki masyarakat yang stabil dan merupakan negara kolonial terbesar di dunia. Dengan terjadinya revolusi industri, maka negara-negara koloni Inggris berperan sebagai sumber bahan baku industri dan merupakan wilayah pemasaran barang-barang hasil manufaktur

Kehidupan masyarakat sebelum Revolusi Industri terkonsentrasi di pedesaan yang mengandalkan penghasilan dari sektor pertanian yang pendapatannya sangat minim dan terbatas. Namun dengan terjadinya Revolusi Industri, lapangan kerja di sektor manufaktur mulai meningkat sehingga penghasilan dan taraf hidup kehidupan masyarakat berangsur membaik.

Faktor kunci terjadinya Revolusi Industri juga dipengaruhi oleh timbulnya revolusi di bidang ilmu pengetahuan yang mulai berkembang sejak pertengahan abad ke16. Saat itu muncul banyak ilmuwan yang mengembangkan ilmu pengetahun dengan melakukan riset dan penelitian. Sektor industri yang mengawali Revolusi Industri 1.0 , diantaranya :

1. Industri Tekstil Di awal era industrialisasi dan mekanisasi, inovasi di sektor industri tekstil mengalami perkembangan yang luar biasa. Hal ini diawali dengan pembuatan mekanisasi mesin pintal. Mesin pintal merupakan temuan inovasi yang mengubah corak sektor industri tekstil. Produksi tekstil yang sebelumnya menggunakan tenaga manusia berubah menggunakan tenaga mesin yang tentu bisa lebih efisien dan efektif. Produktivitas produksi tekstil mengalami peningkatan berlipat-lipat .Tumpuan industri tekstil yang semula menggunakan tenaga manusia berubah menjadi tenaga mesin.

2. Industri Besi dan Baja Perkembangan inovasi di sektor pertambangan juga mengalami kemajuan pesat. Dengan ditemukannya inovasi produksi ,proses pembuatan besi dan baja bisa lebih murah. Biaya proses pembuatan besi dan baja murah merupakan tonggak sejarah berkembangnya industri permesinan dan transportasi. Besi dan baja memperkokoh perkembangan revolusi industri berikutnya. Besi dan baja keduanya merupakan bahan penting yang digunakan untuk pembuatan berbagai peralatan dan infrastruktur penting lainnya.

3. Industri Transportasi Sebelum revolusi industri barang-barang hasil produksi diangkut dengan menggunakan tenaga hewan. Namun setelah ditemukannya mesin uap dan kapal uap proses pengiriman barang produksi ke lokasi yang jauh bisa menggunakan kapal laut dan kereta api.

\section{Revolusi industri 2.0}

Menurut Inovasi.com (2018) Pada periode ini terjadi kemajuan industri yang sangat cepat di Inggris, Jerman, Amerika, Perancis, dan jepang. Selanjutnya revolusi industri ini menyebar ke seluruh Eropa dan Amerika. Revolusi industri 2.0 ini merupakan kelanjutan yang tidak terpisahkan dari revolusi industri sebelumnya yang mulai di Inggris pada abad ke-18. Revolusi Industri 2.0 dikenal 
juga dengan revolusi teknologi dimana dalam periode ini terjadi lompatan besar dan radikal dalam perkembangan teknologi dan budaya masyarakat.

Inovasi pada periode ini merupakan pengembangan industri sebelumnya dengan berbasis ilmu pengetahuan dan teknologi dan berlangsung sekitar tahun 1900- 1960 yang bercirikan dengan ditemukannya mekanisasi sistem produksi massal dengan menggunakan jalur perakitan yang lebih efektif dan efisien, serta adanya standarisasi mutu dan kualitas. Beberapa inovasi dan kemajuan pada periode Revolusi Industri 2.0 antara lain :

1. Pengembangan sumber daya energi seperti minyak bumi, batu bara sebagai sumber bahan bakar baru.

2. Periode awal teknologi listrik yaitu penemuan arus listrik AC dan DC yang bisa difungsikan untuk pembuatan motor listrik (elektrifikasi).

3. Inovasi baru produksi besi dan baja dalam skala besar.

4. Produksi massal mobil dan pesawat sebagai alat transportasi massal.

5. Meluasnya pemakaian mesin industri untuk manufaktur.

6. Meluasnya penggunaan telegraf yang memungkinkan untuk melakukan komunikasi jarak jauh.

7. Penggunaan teknologi listrik yang diterapkan ke dalam teknologi transportasi dan telekomunikasi merupakan lompatan besar bagi perkembangan di sektor industri.

\section{Revolusi industri 3.0}

Menurut Inovasi.com (2018) Perkembangan jaman mendorong kita untuk melakukan inovasi. Di mulai dengan Revolusi industri 1.0 yang ditandai dengan ditemukannya mesin untuk industri, llu revolusi industri 2.0 ditandai dengan penemuan teknologi listrik untuk industri dan berikutnya revolusi industri ke-3 yang di awali dengan munculnya teknologi informasi dan elektronik yang masuk ke dalam dunia industri yaitu sistem otomatisasi berbasis komputer dan robot.

Peralatan industri sudah tidak lagi dikendalikan oleh manusia, namun sudah dikendalikan oleh komputer atau lebih dikenal dengan istilah komputerisasi. Pada periode ini th 1960-2010 melahirkan inovasi pengembangan sistem perangkat lunak untuk memanfaatkan perangkat keras elektronik. Banyak penemuanpenemuan dan pembuatan perangkat elektronik yang memungkinkan untuk melakukan otomatisasi operasional mesinmesin menggantikan peran operator produksi. Beberapa inovasi dan kemajuan pada periode Revolusi Industri 3.0 antara lain: Teknologi computer, akses internet, peralatan elektronik smartphone, inovasi sistem perangkat lunak, inovasi dan pengembangan sumber energi baru.

\section{Revolusi industri 4.0}

Menurut Inovasi.com (2018) Tibalah saatnya kita memasuki revolusi industri 4.0 yaitu era yang ditandai dengan adanya konektivitas manusia, data, dan mesin dalam bentuk virtual atau dikenal dengan istilah cyber physical. Perkembangan revolusi industri membawa perubahan yang sangat cepat dengan tujuan mulia menciptakan kualitas kehidupan yang lebih baik. Pada era industri 4.0 ini ada pergeseran trend inovasi ke arah teknologi digital. 
Di era revolusi industri 4.0 memungkinkan otomatisasi di semua bidang untuk mencapai produktivitas yang efektif dan efisien. Penerapan sistem informasi rantai pasokan digital ke seluruh unit kerja akan meminimalkan peran manusia sebagai operator. Secara umum di era industri 4.0 ini peran tenaga manusia berubah dari peran operator menjadi seorang ahli dengan kompetensi yang tinggi. Istilah lain dari revolusi industri 4.0 adalah revolusi digital dan era disrupsi teknologi. Semua bidang akan menggunakan otomatisasi sistem pencatatan dengan komputer. Salah satu karakteristik unik dari revolusi industri 4.0 adalah penerapan kecerdasan buatan dalam semua bidang industri. Revolusi industri 4.0 berasal dari sebuah proyek yang diprakarsai oleh pemerintah jerman untuk mempromosikan komputer manufaktur. Revolusi generasi empat ini ditandai dengan munculnya komputer canggih, robot pintar, kendaraan tanpa kemudi, yang memungkinkan manusia lebih mengoptimalkan fungsi otak.

\section{Peluang di zaman revolusi industri 4.0}

Menurut Inovasi.com (2018) Di era industri saat ini akan banyak peluangpeluang yang bisa dikembangkan. Ini semua bergantung pada kreativitas untuk mencari dan menemukan peluang yang bertebaran di bidang industri masing-masing. Revolusi industri 4.0 akan banyak mengubah industri dan karakter pekerjaan. Menghadirkan lini-lini usaha baru, lapangan kerja baru, profesi baru yang tidak terpikirkan sebelumnya. Tuntutan kemampuan yang dibutuhkan di era industri 4.0 berubah mengikuti perkembangan teknologi .Untuk bisa bersaing di era industri 4.0, kita harus mampu membaca dan responsif terhadap perubahan dan membekali diri dengan keterampilan terkini.

\section{Ancaman di zaman revolusi industri 4.0}

Menurut Inovasi.com (2018) Di sisi lain pada saat yang sama kehadiran revolusi industri 4.0 akan mengancam lini usaha yang ada, karena profesi dan lapangan kerja digantikan oleh sistem otomasi dan robot. Penggunaan tenaga robot berdampak pada biaya yang lebih murah, efektif dan efisien. Pada era industri 4.0, manusia akan hidup di dalam ketidakpastian, oleh karena itu kita harus memiliki kemampuan untuk memprediksi masa depan. Kita harus memiliki kemampuan untuk merespon perubahan dengan arif dan bijaksana. Kehadiran industri 4.0 akan mengancam keberadaan perusahaan-perusahaan yang telah mapan. Disruptif teknologi hadir begitu cepat dan sudah banyak kisah perusahaan besar yang tumbang dengan meninggalkan kesedihan yang mendalam. Kecepatan pelaku bisnis dalam merespon suatu perubahan sangat menentukan kemajuan untuk masa mendatang. Persaingan bisnis tidak lagi kasat mata, karena teknologi digital mampu menembus tatanan yang ada. Secara fisik tidak terlihat adanya pesaing, namun kenyataannya secara virtual banyak sekali pesaing.

\section{Rahasia sukses di era revolusi industri 4.0}

Menurut Inovasi.com (2018) Apa yang harus kita persiapkan dalam menghadapi revolusi industri 4.0?. Seperti yang kita ketahui bahwa model industri 4.0 adalah kombinasi gabungan dari beberapa inovasi teknologi terbaru seperti teknologi informasi dan komunikasi, sistem jaringan, big data dan cloud 
computing, virtualisasi, dll. Oleh sebab itu, mempersiapkan diri dengan meningkatkan kompetensi di bidang teknologi digital adalah sebuah keniscayaan dan keharusan. Selain itu secara mental kita harus mempersiapkan ketahanan, kemampuan beradaptasi, keterampilan berpikir kritis dan kemampuan berinovasi.

\section{METODE PENELITIAN}

Metode yang digunakan adalah me-review sumber - sumber referensi terkait dengan manajemen pelabuhan dan pemasaran pelabuhan. Analisis dimulai dari kebutuhan industry 4.0, perkembangan teknologi di kepelabuhanan, kemudian Sumberdaya Manusia yang kompetitif.

\section{HASIL DAN PEMBAHASAN}

\section{Pelabuhan di Indonesia}

Indonesia sangat bergantung pada transportasi maritim. Secara geografis, Indonesia dianggap sebagai negara kepulauan terbesar di dunia dengan lebar $1.870 \mathrm{~km}$, panjang $5.200 \mathrm{~km}$ dan luas total 1.905 juta km2. Negara ini terdiri dari 5 pulau besar seperti Papua, Jawa, Sulawesi, Kalimantan dan Sumatera. Selanjutnya, Indonesia memiliki salah satu garis pantai terpanjang di dunia, yaitu $80,791 \mathrm{~km}$ (Dijk et al, 2015). Sebagai kepulauan dari 17.000 pulau, tranportasi laut Indonesia juga melakukan fungsi vital yang menghubungkan masyarakat dan pedagang, baik domestik maupun internasional. Jaringan maritim Indonesia secara signifikan lebih maju daripada udara, hampir $90 \%$ perdagangan internasional dilakukan melalui laut (Dijk et al, 2015).

Menurut Kementerian Perekonomian (2011), Indonesia juga memiliki akses langsung ke negara berkembang seperti India dan China. Selanjutnya, Indonesia berfungsi sebagai jembatan antara dua benua (Asia dan Oceania) dan dua samudra (Pasifik dan India). Dari sudut pandang maritim, lokasi geografis yang strategis dianggap menguntungkan dan mendapat manfaat dari kegiatan maritim. Penelitian yang dilakukan pada tahun 2015 oleh Kementerian Kelautan dan Perikanan menyatakan bahwa potensi jangka panjang pendapatan maritim Indonesia hingga US \$ 800 miliar per tahun, yang diperoleh dari berbagai sektor seperti pelayaran, lepas pantai, perikanan dan pariwisata laut (Dijk et al., 2015).

Pendapatan yang diperoleh dari sektor maritim saat ini berkontribusi $20 \%$ dari GDP Inonesia. Sistem pelabuhan Indonesia disusun menjadi sistem hirarkis yang terdiri dari sekitar 1.700 pelabuhan. Pelabuhan- pelabuhan tersebut dapat dibagi menjadi pelabuhan komersial, khusus, tidak komersial dan pelabuhan perikanan. Ada sekitar 111 pelabuhan komersial (Dijk et al., 2015). Saat ini, 25 pelabuhan strategis yang menjembatani transportasi laut domestik dan internasional. Menurut Dijk dkk. (2015) pelabuhan terbesar adalah: Tanjung Perak, Tanjung Priok, Belawan dan Makassar. Pelabuhan komersial dibagi secara geografis dan ditunjuk untuk dikelola oleh perusahaan milik negara PT Pelabuhan Indonesia I, II, III dan IV.

\section{Sistem Teknologi Informasi dan Kinerja Pelabuhan}

Dalam hal ini, pengukuran kinerja pelabuhan harus didukung oleh investasi dalam hal kemampuan pengumpulan data dan mendukung platform teknologi 
komunikasi dan informasi yang dapat menurunkan biaya pengumpulan dan analisis data. Operator pengiriman berurusan dengan sejumlah besar data, diperlukan sistem informasi untuk mengumpulkan, memproses dan menggunakan data ini untuk mendapatkan informasi penting untuk pengambilan keputusan dan untuk memfasilitasi proses transportasi antara pelaku pasar yang berbeda (UNCTAD, 2004).

Salah satu sektor industri di indonesia yang telah menerapkan industri 4.0 adalah sektor kepelabuhanan, logistik, maupun pelayaran. Pemerintah melalui Kementerian Perhubungan telah menggunakan INAPORTNET sistem. INAPORTNET adalah portal elektronis yang terbuka dan netral guna memfasilitasi pertukaran data dan informasi layanan kepelabuhanan secara cepat, aman, netral dan mudah yang terintegrasi dengan instansi pemerintah terkait, badan usaha pelabuhan dan pelaku industri logistik untuk meningkatkan daya saing komunitas logistik Indonesia. Selain itu, pelabuhan juga menggunakan sistem DO online. Pelindo selaku operator pelabuhan pun telah mulai untuk melakukan digitalisasi pada beberapa layanan mereka.

Beberapa pelabuhan telah menggunakan sejumlah teknologi informasi dan komunikasi baru sejak diperkenalkannya sistem EDI pada pertengahan tahun 1980an (Rasha, 2016). Internet memfasilitasi pengiriman data yang lebih murah melalui berbagai teknologi berbasis web. Penerapan teknologi sangat penting dalam perbaikan kualitas dan produktivitas posisi persaingan pelabuhan (Noteboom dkk, 1997).

Teknologi dapat mempermudah industri dalam melakukan inovasi yang akan memberikan nilai tambah bagi perusahaan. Aplikasi bisnis TI dalam bisnis pengiriman dapat dikelompokkan menjadi tiga segmen utama: - Dokumentasi dan transfer elektronik data EDI: pelacakan kargo, dokumentasi elektronik, dll. - Ecommerce atau e-business: Pendaftaran online dan penyewaan kapal, pengadaan persediaan secara elektronik, pemesanan online dan sistem pembayaran elektronik, dll. - E-marketing: secara bertahap mengambil alih layanan EDI mungkin termasuk penelusuran dan pelacakan, ruang kesepakatan virtual untuk transaksi dan pemrosesan dokumen, penerbitan online, dll.

Meskipun industri 4.0 adalah tren terbaru yang perlu diikuti dalam sistem perindustrian, terdapat beberapa hal yang perlu dipersiapkan dalam penerapannya. Beberapa hal yang perlu diwaspadai dalam penerapan industri 4.0 adalah kesiapan infrastruktur. Contohnya adalah server base data. Kita perlu memperhatikan kemampuan penyimpanan server data tersebut agar tidak terjadi gangguan dalam mengakses data. Selain itu, ketersediaan listrik sebagai sumber energi utama sistem juga harus diperhatikan. Jangan sampai ada kejadian listrik padam dan tidak ada pembangkit cadangan yang berdampak pada lumpuhnya seluruh operasional layanan.

Keunggulan kompetitif pelabuhan berasal dari lokasi, infrastruktur, kapasitas transportasi, integrasi pelabuhan menjadi rantai logistik, operasi pelabuhan yang efektif dan efisien, melalui biaya dan keterampilan tenaga kerja yang kompetitif, peralatan dan teknologi yang diperbarui dan memadai, sistem informasi dan koordinasi pelabuhan yang memfasilitasi pengurangan ketidakpastian, biaya transaksi dan transportasi (Brox, 2014). 
Pengembangan TI maritim diperlukan untuk mendukung target rencana pembangunan nasional dan doktrin Global Maritime Fulcrum. Program ini bertindak sebagai salah satu agenda utama Presiden Joko Widodo, dengan tujuan akhir untuk mengubah Indonesia menjadi pusat dan menjadi salah satu Negara yang berpengaruh utama dari lanskap maritim dunia.

\section{Peran Dan Fungsi Baru Sumber Daya Manusia}

Sumber daya manusia dianggap penting untuk keberhasilan perusahaan di dunia saat ini, namun dalam revolusi Industry 4.0, para peneliti dan praktisi manajemen sudah memprediksi skenario ini untuk mengambil bentuk yang berbeda, mengingat karakteristik perubahan yang diantisipasi. Karakteristik modal manusia yang merupakan kunci keberhasilan adalah pendidikan, pengalaman dan pengetahuan yang perlu dimanfaatkan organisasi untuk mencapai kesuksesan dunia yang kompetitif. Teori modal manusia menganggap bahwa pengetahuan membawa keterampilan kognitif yang lebih besar kepada individu, sehingga mendorong potensi produktivitas dan efisiensi mereka untuk berkembang kegiatan. Dari perspektif nasional, modal manusia dapat didefinisikan sebagai:

"Modal manusia dapat didefinisikan sebagai seperangkat pengetahuan, kemampuan dan keterampilan, yang digunakan dalam kegiatan, proses dan layanan yang berkontribusi untuk merangsang pertumbuhan ekonomi ". (Liza, 2019)

Untuk menjawab tantangan perkembangan teknologi dalam industry 4.0 tersebut diperlukan adanya peran dan fungsi baru sumber daya manusia, bukan hanya peran administratif namun melangkah lebih jauh pada peran dan fungsi bisnis dan strategis sebagai berikut : 1. Sebagai Employee Champion. Peran dan fungsi ini berorientasi pada pentingnya tingginya moral karyawan (high employee morale) untuk terus berkomitmen dan kontribusi dalam mencapai keberhasilan organisasi. 2. Sebagai Agen Perubahan (Change Agent). dituntut untuk memiliki inisiatif dalam melakukan perubahan yang terutama fokus pada penciptaan kinerja team (high-performing teams), megurangi waktu siklus dalam berinovasi (reducing cycle time for innovation), dan mengimplementasikan teknologi baru yang telah didefinisikan dan dikembangkan dalam waktu yang relatif cepat.

Disamping Tuntutan Revolusi 4.0 yang memerlukan peningkatan keterampilan (up-skilling) atau pembaruan keterampilan (reskilling) untuk tenaga kerja. Lembaga pendidikan juga memiliki peran penting dalam menyiapkan sumberdaya manusia yang siap dalam era revolusi industri 4.0. Disadari bahwa, kemajuan teknologi digital dan internet pastilah berawal dari dunia pendidikan.yang lebih duluan mengalami kemajuan.

Pelaku usaha industri kemaritiman seperti perusahaan pelayaran, pemilik kapal, dan tidak terkecuali perguruan tinggi kemaritiman segera mengevaluasi dan menyesuaikan dengan situasi dan tuntutan perkembangan di lapangan. Hal ini sejalan dengan pendapat Meade (dalam Lloyd's List,2017) yang mengemukakan revolusi industri 4.0 banyak menggunakan model digital dan canggih mengharuskan seluruh pihak yang terlibat atau stakeholders mengevaluasi apa yang telah diterapkan dan harus menyesuaikan dengan kebutuhan.

Digital disruption era memaksa pelaku usaha di industri kemaritiman untuk lebih selektif dalam hal menerima para lulusan dari perguruan tinggi 
kemaritiman yang siap bekerja dengan tantangan era baru, dimana segala usaha yang dihadapi melibatkan kecanggihan teknologi dan literasi data. Tuntutan industri kemaritiman ini menjadi tantangan bagi Perguruan Tinggi Kemaritiman di Indonesia dalam menyiapkan lulusannya, agar kompetensi lulusan mampu bersaing dan sesuai dengan kebutuhan dunia kerja baik dalam pengelolaan pelabuhan maupun sebagai perwira di atas kapal. Disamping itu lulusan juga dituntut untuk lebih inovatif dan adatif terhadap kemajuan teknologi berbasis digital.

Untuk menghasilkan lulusan berkualitas sesuai harapan, Perguruan Tinggi Kemaritiman harus melakukan berbagai analisis terkait dengan pengelolaan pendidikan, sehingga akan dapat menentukan strategi-strategi sesuai dengan capaian komptensi lulusan yang diharapkan. Pengelolaan pendidikan yang berorientasi global akan dapat menjawab berbagai kebutuhan di pasar kerja, melalui penyiapan sarana dan prasarana pembelajaran berbasis teknologi informasi, sumber daya manusia yang berkualitas, dan merekonstruksi kurikulum dengan pendekatan human digital.

\section{SIMPULAN}

Tuntutan Revolusi Industri 4.0 membutuhkan SDM yang memiliki kompetensi yang dapat merefleksikan kecanggihan teknologi dan literasi data yang berbasis pada kecepatan perkembangan teknologi sehingga akan lebih inovatif dan adatif pada lingkungan kerjanya. Tuntutan Revolusi 4.0 memerlukan pelaksanaan program peningkatan keterampilan (up-skilling) atau pembaruan keterampilan (reskilling) para tenaga kerja atau lulusan perguruan tinggi berdasarkan kebutuhan dunia industri saat ini

\section{DAFTAR PUSTAKA}

Brox, M.S., (2014). Competitive global ports for regional economic development: The Port of Valencia, Planet Europe.

Dijk, C. van, Mheen, P. van de \& Bloem, M., (2015). Indonesia Maritime Hotspot. Maritime by Holland, Amsterdam.

Khalik, (2019). PERUBAHAN PERAN DAN TRANSFORMASI FUNGSI SUMBER DAYA MANUSIA DALAM MEWUJUDKAN GOOD CORPORATE GOVERNANCE DAN CORPORATE SOCIAL RESPONSIBILITY PADA IAIN SULTHAN THAHA SYAIFUDDIN JAMBI. https://media.neliti.com/media/publications/56384-ID-none.pdf. Diakses tanggal 8 november 2019.

Notteboom, T dan Yap, W. Y, (2012). Port Competition and Competitiveness, dalam Blackwell Companion to Maritime Economics, Diedit oleh Talley, W. K., John Wiley \& Sons Ltd, Chichester, pp. 549-571.

Nurqamar, Insany Fitri. dan Asty Almaida, (2018). Industri Kepelabuhan Dan Peran Teknologi Informasi (TI) Untuk Peningkatan Daya Saing. JBMI Vol. 15 No. 2 Oktober 2018. 
OECD, (2011). Competition in ports and ports services, DAF/COMP (2011) 14, Directorate for Financial and Enterprise Affairs, The OECD Competition Comittee, OECD, Paris.

Pratama, Wegig dan Sri Sartini. (2019). Perguruan Tinggi Kemaritiman Menghadapi Revolusi Industri 4.0. https://www.researchgate.net/publication/334256500_Perguruan_Tinggi Kemaritiman_Menghadapi_Revolusi_Industri_40. Diakses tanggal 8 november 2019.

Rasha, R., (2016). Information technology in modern port management, in The International Maritime Transport and Logistics Conference, pp. 1-20 .

Lervold, Beate Kvamstad. (2017).9 Paths into The Maritime Future.SINTEF. http://haugesundkonferansen.no/content/uploads/2017/02/BeateKvamstad-Lervold.pdf. Diakses 1 Oktober 2018

Lloyd's List. (2017).Digital Disruption-Managing the Transition to Smart Shipping.Lloyd's List Business Briefing.01-13. https://maritimeintelligence.informa.com/resources/key-topics/digitaldisruption. Diakses 15 Oktober 2018

Liza Umami dan Fina Chayati Salamah. (2019). https://www.kompasiana.com/lililiza0966/5d11c93a097f361a8d43ad12/hu man-capital-dan-keunggulan-bersaing-di-era-revolusi-industri-40?page $=$ all. Human Capital dan Keunggulan Bersaing di Era Revolusi Industri 4.0. Diakses tanggal 8 november 2019.

https://krjogja.com/web/news/read/93477/Industri_Pelabuhan_dan_Pelayaran_Ber siap_Hadapi_Revolusi_4_0. Industri Pelabuhan dan Pelayaran Bersiap Hadapi Revolusi 4.0. Diakses tanggal 8 november 2019

http://hubla.dephub.go.id/berita/Pages/INDUSTRI-PELABUHAN-DANPELAYARAN-BERSIAP-HADAPI-REVOLUSI-4.0.aspX. INDUSTRI PELABUHAN DAN PELAYARAN BERSIAP HADAPI REVOLUSI 4.0. Diakses tanggal 8 november 2019

https://www.kompasiana.com/danielmashudi/5c2f217143322f1bad375914/revolu si-industri-4-0-dan-pentingnya-pengembangan-sumber-daya-manusiaindonesia?page $=$ all. 2019. Revolusi Industri 4.0 dan Pentingnya Pengembangan Kualitas Sumber Daya Manusia (SDM) Indonesia. Diakses tanggal 8 november 2019.

https://kemenperin.go.id/artikel/19676/Revolusi-Industri-4.0-Buka-PeluangDongkrak-\%e2\%80\%98Skill\%e2\%80\%99-SDM.2019. Revolusi Industri 4.0

Buka Peluang Dongkrak 'Skill' SDM. Diakses tanggal 8 November 2019. 